\title{
KEPEMIMPINAN DALAM LEMBAGA PENDIDIKAN ISLAM
}

\author{
COLLE SAID \\ Dosen UNISMUH Palu
}

Leadership is the process of activities of someone who has the art / ability to influence, coordinate and move individuals so that cooperation arises regularly in an effort to achieve common goals that have been established I formulated. While educational leadership, namely the process of activities influencing, moving and coordinating individuals, organizations / educational institutions to achieve certain goals that have been formulated. Leader skills operate the organization. is skill to cooperate, motivate and lead and technical skills, namely skills that must be possessed by the principal in using knowledge, methods, techniques, and equipment to complete certain tasks. Other activities that the headmaster must do as a self-developer are learning and observing daily work in the wet environment, observing management activities in a planned and creative way to develop new methods in the learning process and building networks.

Keywords: leadership, Islamic education

Kepemimpinan merupakan proses kegiatan seseorang yang memiliki seni/kemampuan untuk mempengaruhi, mengkoordinasikan dan menggerakkan individu-individu supaya timbul kerjasama secara teratur dalam upaya mencapai tujuan bersama yang telah ditetapkan/dirumuskan. Sedangkan kepemimpinan kependidikan yaitu proses kegiatan mempengaruhi, menggerakkan dan mengkoordinasikan individu-individu, organisasi/lembaga pendidikan tertentu untuk mencapai tujuan yang telah dirumuskan. Keterampilan- serang pemimpin mengoperasikan organisasi. adalah ketermpilan untuk bekerjasama, memotivasi dan memimpin dan keterampilan teknik yaitu keterampilan yang harus dimilki kepala sekolah dalam menggunakan pengetahuan, metode, teknik, serta perlengkapan untuk meneyelesaikan tugas tertentu. Kegietan-kegiatan lain yang harus dilakukan kepala madrasah sebagai pengembang diri adalah senatiasa belajar dan mencermati pekerjaan sehari-hari di lingkungan madarasah, melakuakn observasi kegiatan manajemen secara terencana dan berfikir kreatif untuk mengembangkan metode-metode baru dalam proses belajar mengajar maupun membangun jaringan.

Kata kunci: Kepemimpinan, pendidikan Islam 


\section{Pendahuluan}

Pendidikan Islam merupakan salah satu wujud upaya untuk menanamkan dan mengembangkan ajaran islam, sehingga tercapai berbagai kematangan khususnya dalam keimanan dan ketaqwaan dalam arti luas.

Pendidikan Islam dapat berjalan dan mampu mencapai tujuan yang dicita-citakan maka perlu meningkatkan profesionalisme pendidik melalui peningkatan kompetensi pendidikan, dan juga kepemimpinan sebuah lembaga atau institut atau organisasi yang menaungi dan menyelenggarakan pendidikan Islam tersebut. Dengan adanya seorang pemimpin yang handal yang mampu membina anggotanya, suatu lembaga akan berhasil dalam menyelenggarakan kegiatannya, termasuk kegiatan pendidikan Islam. Untuk menjadi pemimpin yang tepat dalam organisasi tersebut diperlukan ciri-ciri, karakteristik dan sifat-sifat tertentu.

Di dalam lembaga pendidikan Islam, pemimpin ini benar-benar harus dipersiapkan dan dipilih secara selektif, mengingat peran yang dimainkan pemimpin dapat mempengaruhi keseluruhan organisasi.

Keberhasilan ataupun kegagalan suatu lembaga pendidikan lebih ditentukan oleh faktor pemimpin dari pada faktor-faktor lainnya.

Kata kepemimpinan pendidikan Islam merupakan gabungan kata kepemimpinan dan pendidikan Islam. Defenisi tentang kepemimpinan sangat bervariasi, sebanyak orang yang mencoba mendefinisikan konsep kepemimpinan, defenisi kepemimpinan secara luas meliputi proses mempengaruhi dalam menentukan tujuan organisasi, memotivasi pengikut untuk mencapai tujuan, mempengaruhi kelompok dan budayanya, serta mempengaruhi interpretasi mengenai peristiwa-peristiwa para pengikutnya, pengorganisasian dan aktifitas-aktifitas untuk mencapai sasaran.

Menurut Suharsimi Arikunto kepemimipinan adalah usaha yang dilakukan untuk mempengaruhi anggota kelompok agar mereka dengan suka rela menyumbang kemampuannya 
secara maksimal demi pencapaian tujuan kelompok yang telah ditetapkan. ${ }^{1}$

Hadari Nawawi berpendapat bahwa kemampuan menggerakkan, memberikan motivasi dan mempengaruhi orang-orang agar bersedia melakukan tindakan-tindakan yang terarah pada pencapaian tujuan melalui keberanian mengambil keputusan tentang kegiatan yang dilakukan. ${ }^{2}$

Dalam konteks implementatif menurut Paul Harsey dan Ken Blanchard menyebutkan pengertian lain dari para ahli lainnya mengenai kepemimpianan antara lian: ${ }^{3}$

a. Menurut George R. Tery kepemimpinan adalah aktifitas mempengaruhi orang-orang untuk berusaha mencapai tujuan kelompok secara sukarela.

b. Robert Tannen Baun, Irving R. Weschler dan Fren Mescarik mendefinisikan kepemimpinan sebagai pengaruh antar pribadi yang dilakukan dalam suatu situasi dan diarahkan melalui proses komunikasi pada pencapaian tujuan atau tujuan-tujuan tertentu.

c. Harold Konntz dan Cyril O'Donnel mengemukakan bahwa kepemimpinan adalah upaya mempengaruhi orang-orang untuk ikut dalam pencapaian tujuan bersama.

Kemudian makna kepemimpinan di kaitkan dengan defenisi pendidikan islam, dalam pengertiannya pendidikan islam adalah suatu bimbingan terhadap pertumbuhan jasmani dan rohani menurut ajaran Islam dengan hikmah, mengarahkan, mengajarkan, melatih, mengasuh dan mengawasi berlakunya semua ajaran Islam. Dalam pengertian ini dapat diartikan bahwa di dalam proses pendidikan Islam terdapat usaha mempengaruhi jiwa anak didik melalui suatu proses yang setingkat demi setingkat akan meuju pada tujuan yang telah ditetapkan, yakni menanamkan ahlak dan taqwa serta

1 Suharsimi Arikunto, Organisasi dan Administrasi Pendidikan Teknologi dan Kejuruan (Jakarta: Rajawali Pers, 1990), 183.

2 Hadari Nawawi, Administrasi Pendidikan (Jakarta: Haji Masagung, 1988), 81.

3 Paul Harsey, Ken Blanchard (Ed. Agus Darma), Manajemen Perilaku Organisasi: Pendayagunaan Sumber Daya Manusia (Jakarta: Erlangga, t.t.), 98-99. 
menegakkan kebenaran sehingga terbentuklah manusia yang berkepribadian dan berbudi luhur sesuai dengan ajaran Islam.

\section{Tipologi kepemimpinan}

Dalam menggerakkan atau memotivasi orang lain agar melakukan tindakan-tindakan yang selalu terarah pada pencapaian tujuan organisasi, seorang pemimpin harus memiliki pengetahuan atau kecakapan dan keterampilan yang diperlukan dalam melaksanakan kepemimpinannya. Pengetahuan dan keterampilan tersebut diperoleh dari pengalaman belajar secara teori maupun dari pengalamannya dalam praktek selama menjadi pemimpin. Dalam melaksanakan kepemimpinannya, berbagai cara ditempuh oleh seorang pemimpin, cara-cara yang digunakan merupakan pencerminan sikap dan pandangan pemimpin terhadap orang yang dipimpinnya, yang memberikan gambaran pula tentang bentuk (tipe) kepemimpinan yang dijalankan.

Secara teoritis tipe kepemimpinan yang pokok dapat dibedakan menjadi tiga yaitu $:^{4}$

1. Kepemimpinan Otokratis

Tipe kepemimpinan otokratis merupakan tipe kepemimpinan yang paling tua dikenal manusia, oleh karena itu tipe ini juga merupakan yang paling banyak dikenal. Dalam kepemimpinan yang otokratis, pemimpin bertindak sebagai diktator terhadap anggota-anggotanya. Baginya, memimpin adalah menggerakkan dan memaksa kelompok. Kekuasaan pemimpin yang otokratis hanya dibatasi oleh undang-undang, penafsirnya sebagai pemimpin tidak lain adalah menunjukkan dan memberi perintah. Kewajiban bawahan adalah mengikuti dan menjalankan, tidak boleh membantah ataupun mengajukkan saran.

Pemimpin yang otokratis tidak menghendaki musyawarah, rapat hanyalah sebagai sarana untuk menyampaikan instruksi-instruksi. Setiap perbedaan

4 Ngalim Purwanto, Administrasi dan Supervisi Pendidikan (Bandung: Remaja Rosdakarya, 2002), 48. 
pendapat diantara para anggotanya diartikan sebagi kepicikan, pembangkangan atau pelanggaran disiplin tergadap instruksi yang telah ditetapkan.

Dalam tindakan atau perbuatan, pemimpin tidak dapat diganggu gugat. Supervisi bagi pemimpin yang otokratis hanyalah berarti mengontrol, apakah segala perintah yang telah diberikan itu di taati atau dijalankan dengan baik oleh para anggotanya, hal ini berarti bukan supervisi yang dilakukan tetapi sebagai inspeksi, yaitu mencari kesalahan dari para anggotanya. Jika ada anggota yang tidak taat akan diberi hukuman dan jika ada yang taat dan patuh akan diberi penghargaan bahkan dianak emaskan.

2. Kepemimpinan Laizes Faire

Dalam Kepemimpinan Laizes Faire, sebenarnya pemimpinan tidak memberikan pimpinan. Tipe ini diartikan sebagai membiarkan orang-orang berbuat sekehendaknya. Pemimpin yang termasuk tipe ini sama sekali tidak memberikan kontrol dan koreksi terhadap pekerjaan anggotanya. Pemberian tugas dan kerjasama diserahkan kepada anggotanya tanpa ada petunjuk atau saran dari pemimpin. Kekuasaan dan tanggung jawab bersimpang-siur, berserakan diantara anggota kelompok, dengan demikian mudah terjadian kekacauan. Tingkat keberhasilan oraganisasi dengan kepemimpinan laizes faire ini disebabkan karena kesadaran dan dedikasi beberapa anggota kelompok, dan bukan karena pengaruh dari pemimpinnya.

Dalam tipe kepemimpinan laizes faire ini, biasanya struktur organisasinya tidak jelas dan kabur. Segal kegiatan tanpa rencana yang terarah dan tanpa pengawasan dari pimpinan.

3. Kepemimpinan Demokratis

Pemimpin yang bertipe demokratis menafsirkan kepemimpinannya bukan sebagai diktator, melainkan sebagai pemimpin ditengah-tengah anggota kelompoknya. Pemimpin yang demokratis selalu berusaha menstimulasi anggotanya agar bekerja secara kooperatif untuk mecapai tujuan bersama. 
Pemimpin demokratis mempunyai kepercayaan diri sendiri dan menaruh perhatian dan kepercayaan pada anggota bahwa mereka mempunyai kesanggupan bekerja dengan baik dan bertanggungjawab. Pemimpinan yang demokratis selalu memupuk rasa kekeluargaan dan persatuan, selalu membangun semangat anggota kelompok dalam menjalankan dan mengembangkan daya kerjanya.

Faktor-faktor yang mempengaruhi kepemimpinan pendidikan islam

\section{Pemimpin}

Pemimpin harus memiliki pemahaman yang jujur mengenai siapa dirinya. Pemimpin merupakan salah satu intisari manajemen, sumber daya pokok, dan titik sentral dari setiap aktivitas yang terjadi dalam suatu perusahaan atau lembaga pendidikan. Bagaimana kreativitas dan dinamikanya seorang pemimpin dalam menjalankan wewenang kepemimpinannya akan sangat menentukan apakah tujuan pendidikan dapat tercapai atau tidak. Pemimpin dinamis dan kreatif maka organisasi yang dipimpinnya juga kan semakin dinamis dan aktivitas-aktivitas yang akan dilakukan akan semakin banyak.

Pemimpin harus mengutamakan tugas, tanggung jawab dan membina hubungan yang harmonis, baik dengan atasannya maupun dengan para bawahannya. Jadi, pemimpin harus mengadakan komunikasi ke atas dan ke bawah, baik komunikasi formal maupun komunikasi informal.

\section{Pengikut}

Setiap pengikut mempunyai karakter dan kepribadian yang berbeda-beda. Dengan demikian, pengikut yang berbeda memerlukan gaya kepemimpinan yang berbeda pula. Pendapat ini memang naif dalam situasi kelompok, meski sangat dianjurkan dalam situasi layanan individual, atau kasus per kasus. Danim menyatakan, seorang pemimpin harus mengenal orang-orang yang dipimpinnya.

Bagi pimpinan, titik awal yang mendasar adalah memiliki pengetahuan yang baik mengenai sifat dasar manusia, 
seperti kebutuhan, emosi dan motivasi. ${ }^{5}$ Kondisi seperti ini pernah dilakukan oleh Rasulullah. Rasulullah Saw pernah berwasiat kepada orang yang berbeda dengan wasiat yang berbeda pula dan juga pernah menjawab pertanyaan yang sama diajukan kepada beliau oleh orang yang berbeda dengan jawaban yang berbeda pula. Hal ini berarti Rasulullah Saw memperhatikan keadaan yang minta wasiat, dan beliau memberikan sesuatu yang lebih dibutuhkan oleh orang yang minta wasiat tersebut. ${ }^{6}$

\section{Situasi}

Kepemimpinan tidak berada dalam situasi yang kosong. Dia selalu berada dalam situasi, meski semua situasi adalah berbeda. Seorang pemimpinan harus selalu respek terhadap situasi yang terjadi. Pemimpin harus belajar dari pengalaman, meminta pendapat pihak ketika menggunakan keyakinan atas nilai-nilai dan intuisi sering kali efektif untuk membuat keputusan dalam situasi yang sangat sulit. Di sinilah dapat dikatakan bahwa seorang pemimpin itu memerlukan kecerdasan adversarial, yaitu kemampuan diri untuk cepat keluar dari situasi sulit dengan tindakan yang benar atau beresiko paling kecil.

4. Komunikasi

Pemimpin yang baik adalah komunikator yang baik. Sebagian besar waktu yang terpakai untuk kerja kepemimpinan adalah berkomunikasi, baik internal maupun eksternal. Istilah komunikasi berasal dari bahasa latin "comunicatio" yang berarti "pemberitahuan" atau "pertukaran pikiran". Berdasarkan penjelasan diatas, komunikasi merupakan proses penyampaian pikiran atau perasaan oleh seseorang kepada orang lain dengan menggunakan lambang-lambang yang bermakna sama bagi kedua pihak. ${ }^{7}$

5 Danim, Sudarwan, Kepemimpinan Pendidikan: Kepemimpinan Jenius $(I Q+E Q)$, Etika, Perilaku Motivasional, dan Mitos. (Bandung: Alfabeta, 2010), 12.

${ }^{6}$ Yusuf Qardawi, Sunnah Masdaran lil Ma'rifah wal Hadharah, (Kairo: Dar Al Syuruq, 1997), 136.

${ }^{7}$ Effendy, Onong Uchjana, Human Relations dan Public Relations, (Bandung: Mandar Maju, 1993), 11. 
Purwanto mengungkapkan beberapa faktor yang mempengaruhi perilaku pemimpin. Faktor yang dimaksud adalah:

1. Keahlian dan pengetahuan yang diliki oleh pemimpin untuk menjalankan kepemimpinannya.

2. Jenis pekerjaan atau lembaga tempat pemimpin itu melaksanakan tugas jabatannya.

3. Sifat-sifat kepribadian pemimpin.

4. Sifat-sifat kepribadian pengikut dan kelompok yang dipimpinnya.

5. Sangsi-sangsi ada di tangan pemimpin.

Pemimpin sebagai pengatur sebuah lembaga pendidikan Islam mempunyai fungsi dan peran tersendiri. Untuk dapat menjalankan fungsi dan perannya dengan baik, maka seorang pemimpin harus mempunyai sifat-sifat yang baik. Menurut Soebagio Atmodiwirio, kepemimpinan pendidikan memerlukan perhatian utama karena melalui kepemimpinan yang baik kita harapkan lahirnya tenaga-tenaga yang berkualitas dalam berbagai bidang baik sebagai pemikir maupun pekerja.

Secara profesional, untuk mewujudkan tenaga-tenaga profesional tersebut sebagai produk pendidikan, dibutuhkan figur pemimpin yang handal.

Menurut Kartini Kartono, fungsi kepemimpina adalah memandu, membantu, membangun atau memberi motivasi kerja, mengarahkan organisasi, menjalani jaring-jaring komunikasi yang baik, memberikan supervisi atau pengawasan yang efisien dan membawa para pengikutnya pada sasaran yang ingin ditinjau sesuai dengan ketentuan dan perencanaan. ${ }^{8}$

Peran dan fungsi seorang pemimpin, akan sangat menentukan kemana dan akan menjadi apa sebuah lembaga pendidikan yang dipimpinnya. Sehingga dengan kehadiran seorang pemimpin akan membuat organisasi menjadi satu kesatuan yang memiliki kekuatan untuk berkembang dan tumbuh menjadi lebih besar.

${ }^{8}$ Kartini Kartono, Pemimpin dan Kepemimpinan, (Jakarta: Bina Aksara, 1988), 61. 
Menurut James A.F Stoner, sebagaimana dikutip Wahjosumidjo, agar kelompok dapat beroperasi secra efektif, seorang pemimpin mempunyai dua fungsi pokok yaitu:

1. Task related atau Problem Solving Function, dakam fungsi ini pemimpin memberikan saran dalam pemecahan masalah serta memberikan sumbangan informasi dan pendapat.

2. Group maintenance function atau social function. Meliputi pemimpin membantu kelompok beroperasi lebih lancar, pemimpin memberikan persetujuan atau melengkapi anggota kelompok yang lain, misalnya menjembatani kelompok yang sedang berselisih pendapat, memperhatikan diskusi-diskusi kelompok. Seorang pemimpin yang efektif adalah seorang pemimpin yang mampu menampilkan kedua fungsi tersebut dengan jelas. ${ }^{9}$

Secara operasional fungsi kepemimpinan, dapat di bedakan dalam lima fungsi pokok kepemimpinan, yaitu:

1. Fungsi Instruksi

Fungsi ini bersifat komunikasi satu arah pemimpin sebagai komunikasi merupakan pihak yang menentukan apa, bagaimana, bilamana, dan dimana perintah itu dikerjakan agar keputusan dapat dilaksanakan secara efektif.

2. Fungsi Konsultasi

Konsultasi itu dimaksudkan untuk memperoleh masukkan berupa umpan balik (feed back) untuk memperbaiki dan menyempurnakan keputusan-keputusan yang telah ditetapkan dan dilaksanakan. Dengan menjalankan fungsi konsultasi dapat diharapkan keputusankeputusan pimpinan, akan mendapat dukungan dan lebih mudah menginstruksikannya, sehingga kepemimpinan berlangsung efektif.

3. Fungsi partisipatif

Dalam menjalankan fungsi ini pemimpin berusaha mengaktifkan orang-orang yang di pimpinnya, baik dalam keikutsertaan mengambil keputusan maupun dalam

${ }^{9}$ Wahjosumidjo. Kepemimpinan Kepala Sekolah, (Jakarta: PT Raja Grafindo Persada, 2005), 41. 
melaksanakannya. Partipatif tidak berarti bebas berbuat semaunya, tetapi dilakukan secara terkendali dan terarah berupa kerjasama dengan tidak mencapuri atau mengambil tugas pokok orang lain. Keikutsertaan pemimpin harus tetap dalam fungsi sebagai pemimpin dan buka pelaksana.

4. Fungsi Delegasi

Fungsi ini dilaksanakan dengan memberikan pelimpahan wewenang membuat/menetapkan keputusan, baik melalui persetujuan maupun tanpa persetujuan dari pemimpin fungsi delegasi pada dasarnya berarti kepercayaan orang-orang penerima delegasi itu harus di yakini merupakan pembantu pemimpin yang memiliki kesamaan prinsip, persepsi, dan aspirasi.

5. Fungsi pengendalian

Fungsi pengendalian bermaksud kepemimpinan yang sukses atau efektif mampu mengatur aktifitas anggotanya secara terarah dan dalam koordinasi yang efektif, sehingga memungkinkan tercapainya tujuan bersama secara maksimal. Fungsi pengendalian dapat di wujudkan melalui kegiatan bimbingan, pengarahan dan pengawasan. Sedangkan menurut Burns, peran atau fungsi kepemimpinan (Leadership Function), adalah sebagai berikut; penentu arah, sebagai agen perubahan, juru bicara dan pelatih. ${ }^{10}$

\section{Penutup}

Dalam sebuah lembaga pendidikan islam dibutuhkan seorang leader atau pemimpin yang mampu megemban tugas dan tanggung jawab sebagai seoarang pemimpin. Sebuah lembaga dapat berjalan dan mencapai target taupun tujuan yang telah ditetapkan perlulah meningkatkan profesionalisme dari seorang pimpinan, agar dapat membawa pengaruh yang positif bagi lembaga tersebut. Dengan adanya seorang pemimpin yang handal akan berhasil dalam menyelenggarakan kegiatannya, termasuk kegiatan pendidikan Islam.

Di dalam lembaga pendidikan Islam, pimpinan ini benar-benar harus dipersiapkan dan dipilih secara selektif,

${ }^{10}$ J.M Burns. Leadership, (New York: Happer, 1987), 111. 
mengingat peran yang dimainkan oleh seorang pimpinan dapat mempengaruhi keseluruhan organisasi.

Maju-mundurnya lembaga pendidikan lebih ditentukan oleh faktor pemimpin dari pada faktor-faktor lainnya. Memang ada keterlibatan faktor-faktor lain dalam memberikan kontribusi kemajuan lembaga, tetapi posisi pemimpin masi merupakan faktor yang paling berpengaruh dalam menentukan nasib suatu lembaga pendidikan islam kedepannya. 


\section{Daftar Pustaka}

Danim, Sudarwan, Kepemimpinan Pendidikan: Kepemimpinan Jenius $(I Q+E Q)$, Etika, Perilaku Motivasional, dan Mitos. Bandung: Alfabeta, 2010

Effendy, Onong Uchjana, Human Relations dan Public Relations, Bandung: Mandar Maju, 1993

Hadari Nawawi, Administrasi Pendidikan, Jakarta: Haji Masagung, 1988

Hasibuan, Malayu S.P, Manajemen: Dasar, Pengertian dan Masalah, Jakarta: Bumi Aksara, 2014

J.M Burns. Leadership, New York: Happer, 1987

Kartini Kartono, Pemimpin dan Kepemimpinan, Jakarta: Bina Aksara, 1988

Ngalim Purwanto, Administrasi dan Supervisi Pendidikan Bandung: Remaja Rosdakarya, 2002

Paul Harsey, Ken Blanchard (Ed. Agus Darma), Manajemen Perilaku Organisasi: Pendayagunaan Sumber Daya Manusia Jakarta: Erlangga, t.t

Shulhan, Muwahid dan Soim, Manajemen Pendidikan Islam: Strategi Dasar Menuju Peningkatan Mutu Pendidikan Islam, Yogyakarta: Kalimedia, 2018.

Suharsimi Arikunto, Organisasi dan Administrasi Pendidikan Teknologi dan Kejuruan, Jakarta: Rajawali Pers, 1990

Sulistyorini dan Fatuhrrohman, Muhammad. Esensi Manajemen Pendidikan Islam: Pengelolaan Lembaga Untuk Meningkatkan Kualitas Pendidikan Islam, Yogyakarta: Kalimedia, 2016.

Wahjosumidjo. Kepemimpinan Kepala Sekolah, Jakarta: PT Raja Grafindo Persada, 2005

Yusuf Qardawi, Sunnah Masdaran lil Ma'rifah wal Hadharah, Kairo: Dar Al Syuruq, 1997 